\title{
THE CHARACTERISTICS OF AFTERSHOCK ACTIVITIES OF DIEN BIEN EARTHQUAKE ON 19 FEBRUARY 2001 AND THEIR RELATION TO THE LOCAL GEOMORPHOLOGICAL, TECTONIC FEATURES
}

\author{
NGO THI LU ${ }^{1,2}$, PHUNG THI THU HANG ${ }^{1,2}$, NGUYEN HUU TUYEN ${ }^{1}$ HA THI GIANG ${ }^{1}$, \\ NGUYEN THANH HAI ${ }^{1}$
}

${ }^{1}$ Institute of Geophysics, Vietnam Academy of Science and Technology. 18 Hoang Quoc Viet, Cau Giay District, Hanoi, Vietnam; e-mail: ngothiluigp@gmail.com

${ }^{2}$ Graduate University of Science and Technology, Vietnam Academy of Science and Technology. 18 Hoang Quoc Viet, Cau Giay District, Hanoi, Vietnam

\begin{abstract}
Ngo Thi Lu, Phung Thi Thu Hang, Nguyen Huu Tuyen, Ha Thi Giang, Nguyen Thanh Hai: The characteristics of aftershock activities of Dien Bien earthquake on 19 February 2001 and their relation to the local geomorphological, tectonic features. Ekológia (Bratislava), Vol. 38, No. 2, p. 189-200, 2019.

This article examines in detail the characteristics of Dien Bien earthquake on 19 February 2001 and its aftershocks. On the basis of the temporal development of aftershocks and the spatial distribution of tectonic faults, five aftershock series have been determined. The analysis of spatial distribution and temporal evolution of these five aftershock series has clarified the development in the source zone of Dien Bien earthquake, which is closely related to the active and recent activities of tectonic faults in the area, especially Lai Chau Dien Bien fault. The comparison between characteristics of aftershock activities of Dien Bien earthquake and geomorphological features as well as tectonic activities in the area has indicated that the magnitude of these aftershocks and their temporal evolution (early or late) depend not only on the closer or further distance compared to the mainshock and the active faults that cause them but also on terrain elevation, slope index, lineament density and their positions relative to other tectonic faults in the studied area.
\end{abstract}

Key words: aftershocks, Dien Bien earthquake, morphotectonic.

\section{Introduction}

On 19 February 2001, at 22:51 (GMT), an earthquake with magnitude $\mathrm{M}=5.3$ occurred 20 $\mathrm{km}$ southwest of Dien Bien Phu. According to the data from International Seismological Centre (ISC), this earthquake was recorded by many international seismic stations in the area. Dien Bien earthquake was accompanied by many aftershocks, some of which had the magnitude of $4 \leq \mathrm{M} \leq 4.8$. It caused much damage to Dien Bien Phu and adjacent areas.

Since the occurrence of this earthquake, a number of studies have been conducted in different directions such as investigating the impact of the earthquake, measuring the mi- 
croseismic oscillations, assessing the ground impact as well as establishing the isoseismic map and examining the aftershock activities (Le Tu Son et al., 2004; Cao Dinh Trieu, 2001; Nguyen Ngoc Thuy et al., 2005). However, these studies are mainly based on seismic data and have not elucidated the development in the hypocentre region as well as its relation to the geomorphological features and the tectonic activities in the area.

Recently, there have been many studies evaluating seismic hazard and partitioning of strong earthquake activity (Mmax) based on the combination of geological, geophysical, geomorphological and seismic data (Ngo Thi Lu et al., 2016, 2017; Nguyen Huu Tuyen, Ngo Thi Lu, 2012; Rodkin et al., 2014).

In addition, the development of science and information technology allows us to use geographic information system, GIS and remote sensing data in a series of studies, such as the risk assessment of landslide risk (Barančoková, Kenderessy, 2014); to use GIS for creation of geohazards map (Magulová, 2009); using modern geological techniques and spatial analysis such as satellite imagery and geographic information to study, assess and establish maps of earthquake risk (Nguyen Hong Phuong et al., 2018), maps of the forest fires risk (Belgherbi et al., 2018); and so on.

On the other hand, with a large number of accompanying aftershocks as mentioned in the aftershock catalogue of Dien Bien earthquake (Le Tu Son et al., 2004), the more detailed studies on the characteristics of aftershock activities and their development in the hypocentre region can be conducted. It allows clarifying the recent activities of a series of tectonic faults in the area. Therefore, in this article, we have investigated the characteristics of aftershock activities of Dien Bien earthquake on 19 February 2001 and studied their relation to geomorphological features and tectonic activities based on the modern geological techniques and combination of seismic data and remote sensing data.

\section{Methods}

\section{Seismic data}

To study the characteristics of aftershock activities of Dien Bien earthquake, first, we have collected the data on its aftershocks. According to data in the aftershock catalogue of Dien Bien earthquake (Le Tu Son et al., 2004), from 19 February 2001 to 9 June 2001, 378 aftershocks with a magnitude of $M \leq 4.8$ have occurred. The earthquake magnitude $(\mathrm{M})$ is determined by the length of recorded tape in accordance with (Nguyen Dinh Xuyen, Nguyen Le Yem, 1980):

$$
\mathrm{M}_{\mathrm{T}}=2.67 \lg \mathrm{T}-2.49(1)
$$

where $\mathrm{T}$ is the length of recorded tape (in second).

On the basis of the experience of seismic data processing staff at the Institute of Geophysics, Vietnam, the length of recorded tape is calculated from the occurrence of wave to the end on the tape (when the wave amplitude is twice as high as the interference amplitude). In addition, this earthquake was also recorded by many international seismic stations in the area (Seismological Bulletin of ISC, 2001).

Amongst 378 aftershocks mentioned above, 29 aftershocks had a magnitude of $M \geq 2.0$, in which 23 aftershocks had a magnitude of $M \geq 2.5$. We have studied the temporal evolution of these aftershocks as well as their spatial distribution. We have also examined their characteristics in the general relation to other strong earthquakes and aftershocks in the adjacent areas (Le Tu Son et al., 2004). The data on Dien Bien earthquake and its aftershocks are presented in Table 1. It should be noted that in Table 1, the magnitude values $\mathrm{M}_{\mathrm{T}}$ according to the length of recorded 
tape have been converted to the magnitude values $\mathrm{M}_{\mathrm{S}}$ according to the surface wave using the following formula (Ngo Thi Lu, 2003):

$$
\mathrm{M}_{\mathrm{S}}=0.98 \mathrm{M}_{\mathrm{T}}+0.10
$$

Furthermore, we have added the dimension parameters of hypocentre of mainshock, which are calculated using the following formula (Shebalin, 1971, 1974) in accordance with (Ngo Thi Lu, 1999):

$$
\begin{aligned}
& \lg \mathrm{L}=0.55 \mathrm{M}-2.0 \\
& \lg \mathrm{W}=0.30 \mathrm{M}-0.75
\end{aligned}
$$

\begin{tabular}{|c|c|c|c|c|c|c|c|c|}
\hline No. & Data & h. m. s. & $\phi^{o} \mathbf{N}$ & $\lambda^{o} \mathrm{E}$ & h (km) & MS & $\mathrm{L}(\mathbf{k m})$ & $\mathrm{W}(\mathbf{k m})$ \\
\hline *(mainshock) & 190201 & 155135.2 & 21.331 & 102.897 & 6.1 & 5.3 & 6.92 & 8.22 \\
\hline 1 & 190201 & 160702.3 & 21.339 & 102.934 & 4.3 & 3.1 & & \\
\hline 2 & 190201 & 161550.3 & 21.345 & 102.941 & 0 & 2.6 & & \\
\hline 3 & 190201 & 164018.9 & 21.298 & 102.927 & 0.8 & 4.2 & & \\
\hline 4 & 190201 & 164118.4 & 21.325 & 102.91 & 0 & 4.2 & & \\
\hline 5 & 190201 & 190250.1 & 21.305 & 102.903 & 0 & 4.8 & & \\
\hline 6 & 190201 & 190251.7 & 21.377 & 102.997 & 10 & 2.3 & & \\
\hline 7 & 190201 & 225831.5 & 21.497 & 102.886 & 1.2 & 2.8 & & \\
\hline 8 & 210201 & 110345.0 & 21.395 & 102.991 & 0 & 3.2 & & \\
\hline 9 & 220201 & 113633.5 & 21.352 & 102.925 & 1.8 & 3.1 & & \\
\hline 10 & 230201 & 175328.9 & 21.518 & 102.916 & 0 & 3.1 & & \\
\hline 11 & 240201 & 221431.1 & 21.335 & 102.928 & 0 & 3.6 & & \\
\hline 12 & 240201 & 223842.5 & 21.587 & 102.915 & 6.5 & 2.9 & & \\
\hline 13 & 040301 & 201846.3 & 21.539 & 102.652 & 10 & 2.7 & & \\
\hline 14 & 040301 & 201949.0 & 21.315 & 102.822 & 0 & 4.0 & & \\
\hline 15 & 040301 & 204055.7 & 21.352 & 102.981 & 10 & 2.2 & & \\
\hline 16 & 040301 & 204153.7 & 21.447 & 102.88 & 0 & 2.9 & & \\
\hline 17 & 050301 & 021207.8 & 21.343 & 102.99 & 10 & 2.6 & & \\
\hline 18 & 050301 & 021303.7 & 21.48 & 102.795 & 0 & 2.7 & & \\
\hline 19 & 050301 & 142237.9 & 21.401 & 102.986 & 10 & 3.1 & & \\
\hline 20 & 050301 & 142339.2 & 21.4 & 103.102 & 0.3 & 2.8 & & \\
\hline 21 & 050301 & 150759.6 & 21.39 & 102.89 & 5.3 & 3.2 & & \\
\hline 22 & 250301 & 132822.2 & 21.3 & 103.011 & 0 & 2.9 & & \\
\hline 23 & 260301 & 224950.4 & 21.47 & 103.093 & 10 & 2.2 & & \\
\hline 24 & 030401 & 043006.9 & 21.415 & 103.16 & 10 & 2.3 & & \\
\hline 25 & 220401 & 123050.2 & 21.292 & 102.909 & 0 & 3.3 & & \\
\hline 26 & 230401 & 155116.8 & 21.31 & 102.825 & 0 & 3.8 & & \\
\hline 27 & 020501 & 140314.5 & 21.318 & 103.09 & 0 & 2.3 & & \\
\hline 28 & 080601 & 073813.6 & 21.338 & 102.946 & 1.8 & 3 & & \\
\hline 29 & 080601 & 140922.6 & 21.233 & 103.058 & 0 & 2.1 & & \\
\hline
\end{tabular}

where $\mathrm{L}$ is the length of hypocentre $(\mathrm{km})$ and $\mathrm{W}$ is the width of hypocentre $(\mathrm{km})$.

T a b le 1. Basic parameters of Dien Bien earthquake and its aftershocks. 
To study the relationship between the aftershocks of Dien Bien earthquake and tectonic activity in the area, we have analysed morphotectonic features of the restricted area that is limited by the coordinates: $\varphi=21.06-21.91^{\circ} \mathrm{N} ; \lambda=$ $102.70-103.39^{\circ} \mathrm{E}$ (Figures 3 and 4 ).

Large-scale topographic maps (1/50,000), digital elevation maps and remote sensing data of the Digital Elevation Model (DEM images) were used to analyse the density of lineaments and geomorphic indicators as the first step to detect the surface deformation associated with tectonic activity.

The $\mathrm{V}_{\mathrm{f}}$ index (the ratio between the valley floor width and its height) reflects deepening of erosion. It allows to estimate the rate of vertical movement of the area. The lower values of $\mathrm{V}_{\mathrm{f}}$ (often close to values 0 with $\mathrm{V}$-shaped valleys) are commonly related to an active uplifted area (Bull, 2007; Bull, McFadden, 1977).

The analysing of remote sensing data includes aerial photography and satellite images with high resolution in order to reveal landscape deformation that are formed by inter-activities of the endogenous-exogenous processes. The morphotectonic indicators for horizontal movement are rectilinear fault scarps, beheaded valleys of minor tributaries, as well as shutter ridges. And component of normal slip is identified by the presence of small-size triangular facets (Zuchiewicz, Cuong, 2002, 2003). Moreover, tectonic data are referenced from the tectonic map in (Nguyen Ngoc Thuy et al., 2005).

\section{Characteristics of aftershock activities of Dien Bien earthquake}

\section{Spatial distribution of aftershocks}

Fig. 1 shows the distribution of epicentres of Dien Bien earthquake and its aftershocks. The aftershocks are numbered from 1 to 29 according to the temporal evolution in the hypocentre (their occurrence time). In consideration of their relation to tectonic faults in the area, it is obvious from Fig. 1 that the major earthquake occurred at the coordinate $\varphi=21.336, \lambda=102.803$, near Lai Chau-Dien Bien (LC-DB) fault, slightly towards the right of this fault. According to the results obtained in Figure 1, the epicentres of aftershocks of Dien Bien earthquake were distributed along this fault, mainly in the northeast (NE)-southwest (SW) direction in an area of about $30 \mathrm{~km}$ wide and more than $40 \mathrm{~km}$ long from Thanh Nua (NE) to Tay Trang (SW), and concentrated more densely in Dien Bien Phu. In addition, the epicentres of aftershocks with greater magnitude were concentrated in a region on the right of this fault with the narrower area of more than $50 \mathrm{~km}^{2}$, more than $10 \mathrm{~km}$ long and about $5 \mathrm{~km}$ wide. The aftershocks with smaller magnitude were distributed outwards on both sides of LC-DB fault and more northwards compared to the mainshock. It is also observed that the LC-DB fault crosses this area in the NE-SW direction and its branch runs in the sub-longitudinal direction. The epicentre of Dien Bien earthquake was very close to the intersection of LC-DB fault with other faults such as Dien Bien-Pakanua, Fumaytun, Thanh Nua-Keo Lom, Kan Ho-Muong Mon faults (Fig.1).

\section{Temporal evolution of aftershocks}

In consideration of temporal evolution of aftershocks and based on the distribution of tectonic faults in the area, it is possible to delineate five epicentre regions of aftershocks of Dien Bien earthquake as in Fig. 1 (below called aftershock series).

- The first aftershock series (I): This series includes the earliest aftershocks following the mainshock. Their epicentres were distributed quite concentratedly in an ellipse-shaped area 


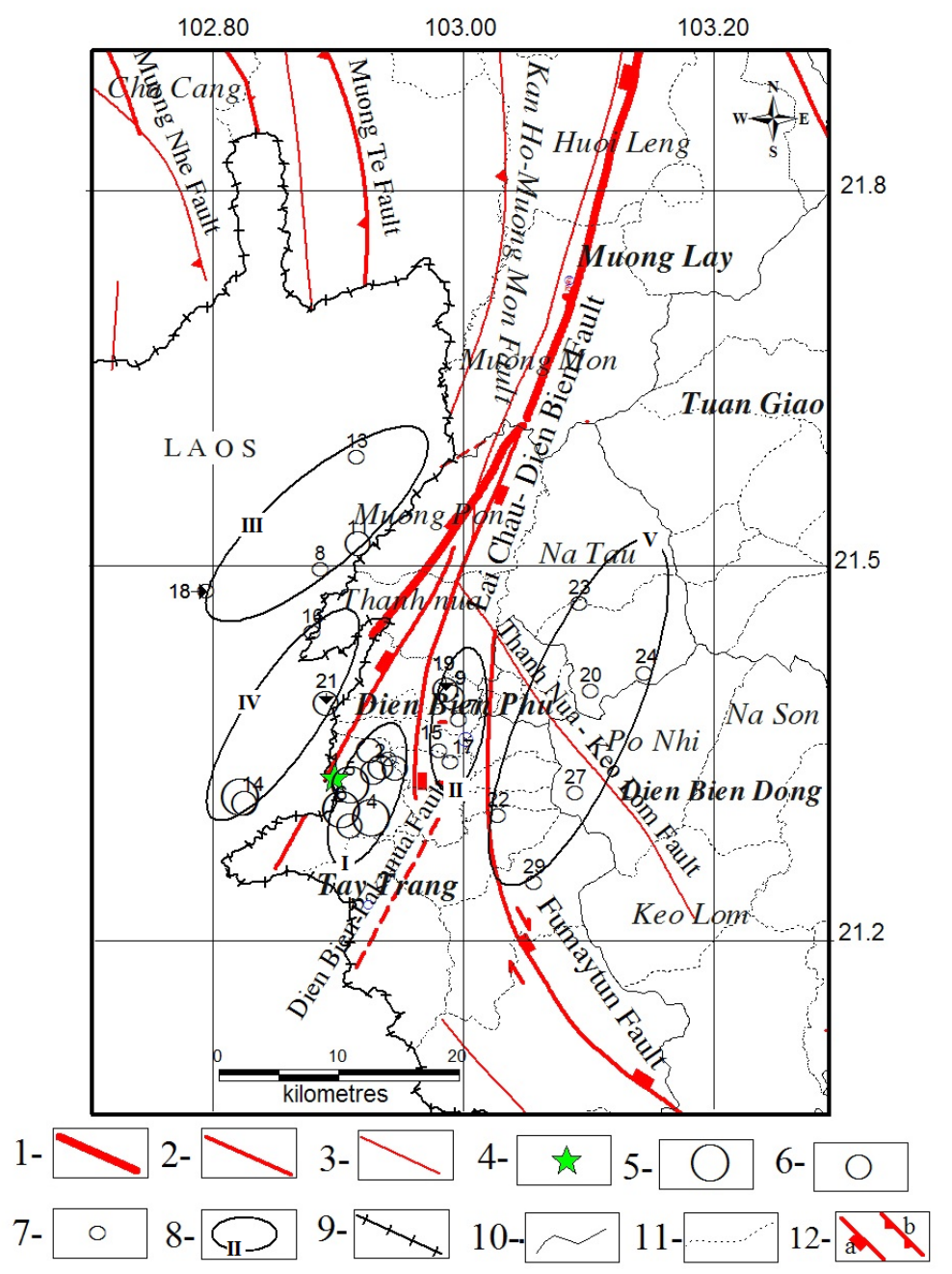

Fig. 1. Spatial distribution and temporal evolution of aftershocks.

Notes: 1 - first-order fault; 2 - second-order fault; 3 - undivided high- order fault; 4 - mainshock; 5 - $4.0 \leq \mathrm{M}$ $<5.0 ; 6-3.0 \leq \mathrm{M}<4.0 ; 7-\mathrm{M}<3.0 ; 8$ - distribution area of aftershock series (I-V); 9 - Vietnam's border; $10-$ district boundary; 11 - commune boundary; 12a - normal fault; $12 \mathrm{~b}$ - reverse fault (tectonic faults after Nguyen Ngoc Thuy et al., 2005).

of $53 \mathrm{~km}^{2}$ with a width of $5 \mathrm{~km}$ and an axis of $10 \mathrm{~km}$ in the NE-SW direction, coinciding with the direction of LC-DB fault. Thus, the dimension and area of distribution of the first aftershock series are relatively consistent with the dimension of hypocentre of mainshock presented in Table 1 (Shebalin, 1971, 1974). It means that the first aftershock series was located 
in the extremely active zone, which was the source zone of Dien Bien earthquake. It can be observed from Fig. 1 and Table 1 that about 15 min after the mainshock, an aftershock with a magnitude of $\mathrm{M}=3.1$ occurred immediately (aftershock 1); its epicentre was located $25 \mathrm{~m}$ slightly eastwards compared to the mainshock and on the right of LC-DB fault in the first aftershock series. The subsequent aftershocks also shifted towards this direction compared to the mainshock (aftershocks 2, 3, 4, 6 and 7) and were distributed quite concentratedly in the first aftershock series. The epicentre of the strongest aftershock with a magnitude of $M=4.8$ was also distributed in this series (aftershock 4).

- The second aftershock series (II): This series consists mainly of the aftershocks that followed the aftershocks of the first series. Their epicentres were also distributed concentratedly in a smaller ellipse-shaped area of about $44 \mathrm{~km}^{2}$ with a width of $4.4 \mathrm{~km}$ and an axis of nearly $13 \mathrm{~km}$ in the sub-longitudinal direction and more northwards compared to the mainshock. It is noteworthy that the second aftershock series lay between two faults towards the right of LC-DB fault and the left of Fumaytun fault. Both segments of these two faults follow the sublongitudinal direction, coinciding with the extending direction of the second aftershock series.

- The third aftershock series (III): This series consists of the aftershocks occurring later than those of the second series with smaller magnitude M. They were extensively distributed in an ellipse-shaped area of about $148 \mathrm{~km}^{2}$ (with a length of $24 \mathrm{~km}$ and a width of 7.9 $\mathrm{km}$ ) towards the left of LC-DB fault and more towards northwest direction compared to the mainshock and the first two aftershock series. Particularly, the third aftershock series seemed to be distributed closer and located at the end of Kan Ho-Muong Mon fault.

- The fourth aftershock series (IV): This series includes the aftershocks that followed the aftershocks of the third series. Their epicentres were distributed on the left of LC-DB fault branch and more towards northwest direction compared to the mainshock, and more towards southeast direction compared to the third aftershock series. They were also distributed in a smaller ellipse-shaped region compared to the third series with a length of about 21.5 $\mathrm{km}$, a width of about $6.1 \mathrm{~km}$, an area of $106 \mathrm{~km}^{2}$ and extended in the NE-SW direction, coinciding with the extending direction of the LC-DB fault.

- The fifth aftershock series (V): This series includes the latest aftershocks (with smaller magnitude M) that were distributed outwards on the right of both LC-DB fault and Fumaytun fault. This series shifted more towards north direction compared to the mainshock and the first aftershock series. They were concentrated in the largest ellipse-shaped area of 239 $\mathrm{km}^{2}$ with a width of about $9.4 \mathrm{~km}$ and an axis of $33 \mathrm{~km}$ in the NE-SW direction, coinciding with the extending direction of LC-DB fault. It is noteworthy that the fifth aftershock series was distributed furthest from LC-DB fault but closer to Fumaytun fault and lay on both sides of Thanh Nua-Keo Lom fault branch.

Thus, the above-described process has shown that the development in the hypocentre region (source zone) of Dien Bien earthquake consists of five aftershock series with the evolution recurring on both sides of LC-DB fault and shifting towards different directions compared to the mainshock: After the mainshock, the first aftershock series occurred on the right side of LC-DB fault in the Dien Bien Phu segment and then the aftershock activities gradually shifted towards east and NE directions on the right of this fault. Subsequently, the aftershock activities developed on the left of LC-DB fault and shifted towards northwest di- 
rection, then slightly towards SW direction and finally extended on the right of LC-DB fault towards the east-NE direction compared to the mainshock. This process is the evidence that not only indicates the consistency of seismic and tectonic data but also confirms the active and recent activities of LC-DB fault and other faults in this area. It is also the cause of Dien Bien earthquake and its aftershock series.

\section{Depth distribution of aftershocks}

The depth distribution of hypocentres of mainshock and its aftershocks is presented in Fig. 2 . It is clear that the hypocentre of Dien Bien earthquake was located at a depth of $6.1 \mathrm{~km}$ and the hypocentres of its aftershocks were located at a depth of 0-10 km, mainly concentrated on the surface (Fig. 2, Table 1). This result shows that Dien Bien earthquake is a shallow earthquake, with the hypocentre located near the Earth's surface.

Relation between characteristics of aftershock activities of Dien Bien earthquake and morphotectonic features in the area

To determine the relationship between characteristics of the aftershock activities of Dien Bien earthquake and geomorphic features caused by tectonic activities in the studied area, we have established the distribution diagram of epicentre of Dien Bien earthquake and its aftershocks based on the digital elevation map (Fig. 3) and distribution map of morphotectonic indicator $\left(V_{f}\right.$ index $)$ and lineament density (Fig. 4).

On the basis of the results obtained from Figs 3 and 4, the spatial distribution and temporal evolution of aftershock series of the Dien Bien earthquake have been examined together with topographic and morphotectonic analysis. It can be observed that all five aftershock series were distributed along deep

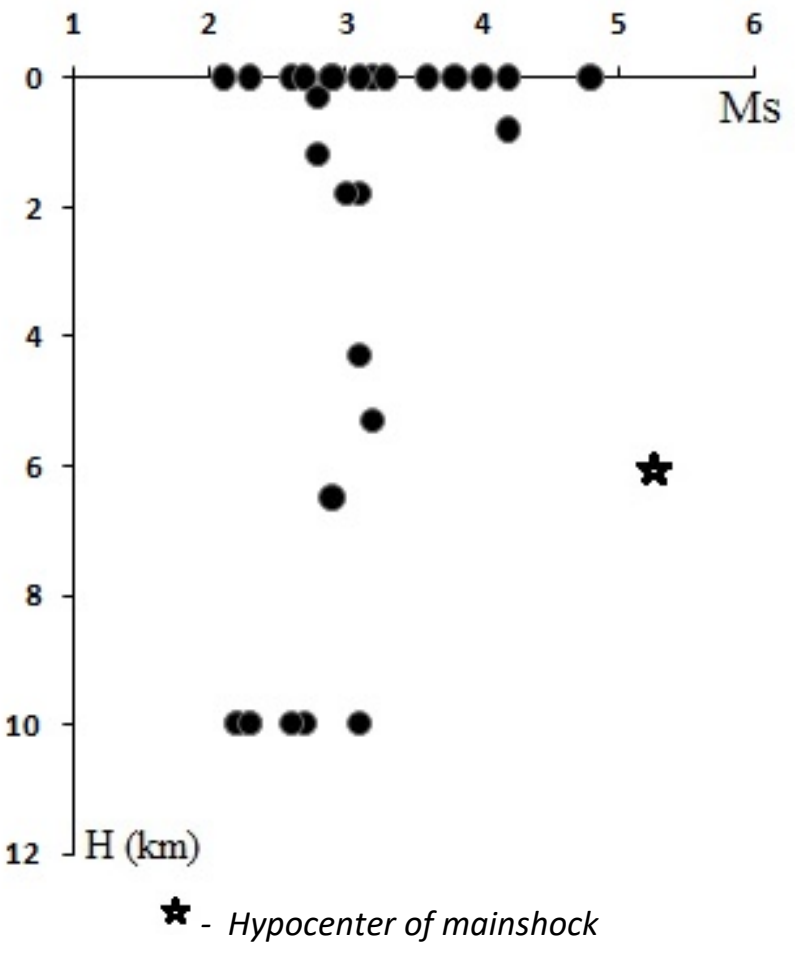

Fig. 2. Depth distribution of hypocenters of Dien Bien earthquake and its aftershocks. 
valleys or steep slopes belong to tectonic fault branches (Fig. 3). The aftershock series with greater magnitude and earlier occurrence time were distributed in deep valleys or their slopes (the first and second series). The weaker and later aftershock series were distributed along steep slopes (the third, fourth and fifth series). It allows us to comment that the active activities of LC-DB fault along with its neighbouring fault branches caused the destruction and movement of matter in the existing geological environment and triggered Dien Bien earthquake and its aftershocks. The occurrence of aftershock series and their magnitude do not only depend on the distance from the mainshock and active faults that cause them but also on the terrain elevation, where they occurred.

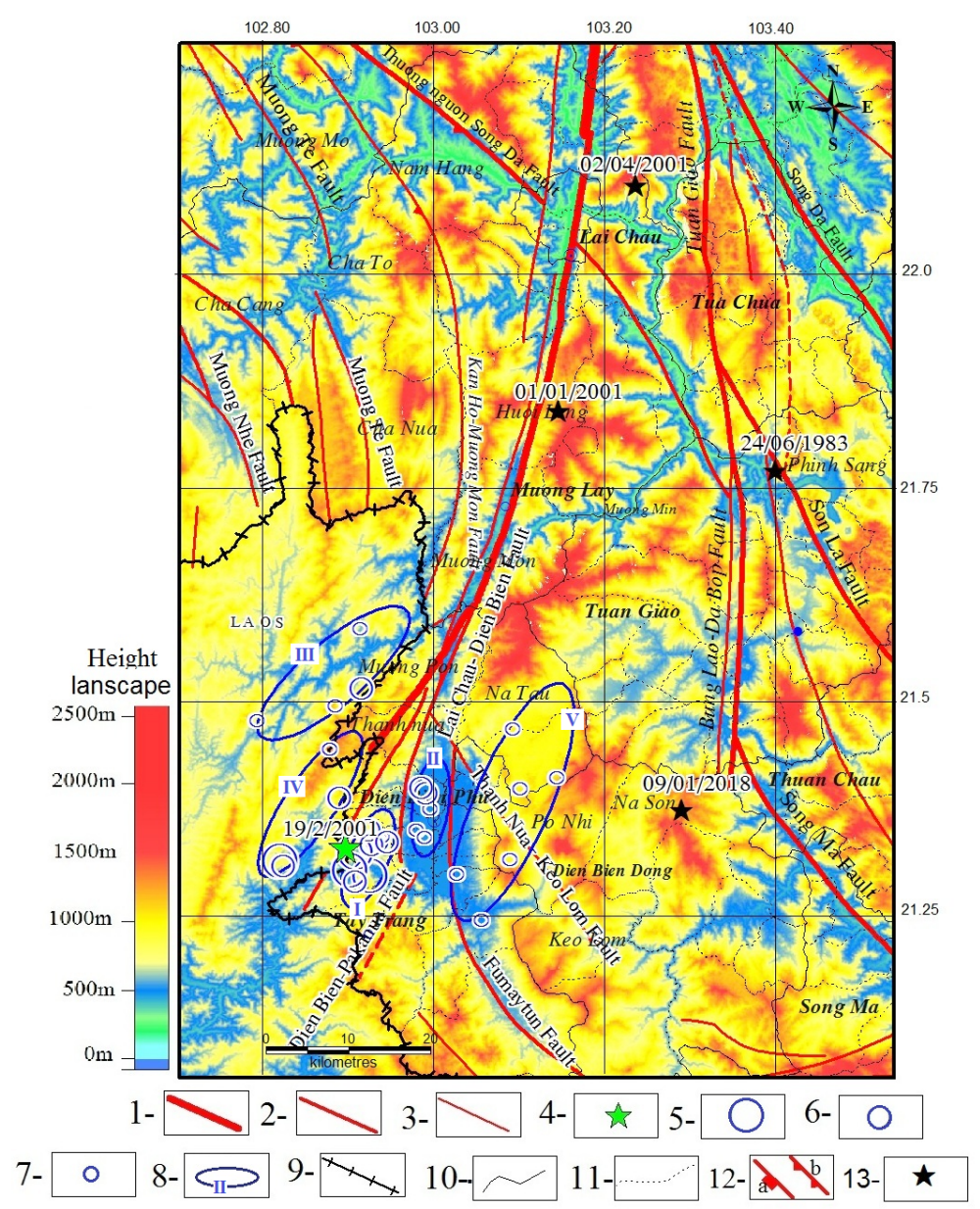

Fig. 3. The characteristics of aftershocks of the Dien Bien earthquake on the digital elevation map. 
It should be noted that the legends of Fig. 3 are similar to those of Fig. 1; 13 in the figure represents the epicentre of the earthquakes, corresponding in Table 2.

Comparison of the aftershock series distribution of the Dien Bien earthquake with distribution of the geomorphic index $\left(\mathrm{V}_{\mathrm{f}}\right)$ and the lineament density on Fig. 4 shows that all five aftershock series are distributed where the geomorphology anomalies are quite high. In particular, the aftershock series with greater magnitude and earlier occurrence time (the first and second series) are distributed in the central of Dien Bien Phu basin, where the highest value of geomorphic index $\left(\mathrm{V}_{\mathrm{f}}=2.2-4.0\right)$, and the lineament density is also relatively high (about $0.35-0.5 \mathrm{~m} / \mathrm{km}^{2}$ ). The weaker and latter aftershock series (the third, fourth and fifth

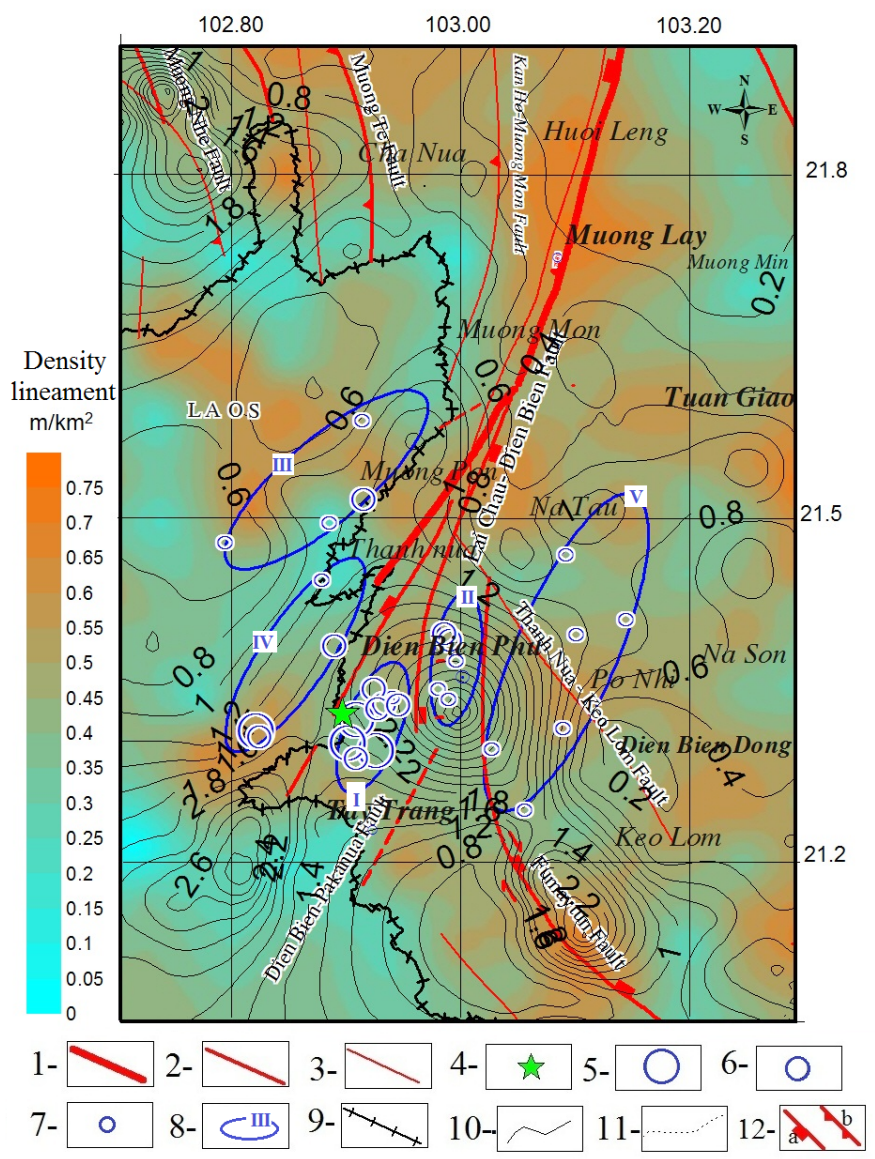

Fig. 4. Relation between characteristics of aftershocks of Dien Bien earthquake and morphotectonic indicator ( $\left.V_{f}\right)$ and lineament density in the studied area.

Notes: 1-9 - are similar to those of 1-9 in Fig. 1; 10 - isoline of geomorphic index value $V_{f}$; 11a - normal fault; $11 \mathrm{~b}$ - reverse fault. 
series) were distributed at the area with lower values $\left(\mathrm{V}_{\mathrm{f}}=0.4-1.4\right)$. However, here the lineament density is higher (approximately $0.55-0.7 \mathrm{~m} / \mathrm{km}^{2}$ ) (Fig. 4).

Thus, the temporal evolution (early or late) and magnitude of aftershock series depend not only on the closer or further distance compared to the mainshock and the active faults that cause them but also on terrain elevation, slope index, lineament density and their positions relative to other tectonic faults in the studied area.

According to the results from the combination of different studying methods such as analysing morphotectonic indicators, age dating of young terraces as well as precise geodetic measurements (Zuchiewicz, Cuong, 2002, 2003; Zuchiewicz et al., 2004), the LC-DB fault zone is a sinistral, sinistral-normal one. It does not only activate with rate of sinistral strike-slip ranging from 2 to $4 \mathrm{~mm} / \mathrm{yr}$ in middle-late Pleistocene and from 0.6 to $2 \mathrm{~mm} / \mathrm{yr}$ in Holocene and also about $1 \mathrm{~mm} / \mathrm{yr}$ at present. The rate of Holocene uplifting is about 0.4-0.6 $\mathrm{mm} / \mathrm{yr}$ in the western part of Dien Bien Phu, exactly where the Dien Bien Earthquake took place on 19 February 2001.

The activities of the LC-DB fault zone are more intensive on the radiating fault branches that develop to both two sides in its SW (Thanh Nua-Keo Lom, Fumaytun, Dien Bien-Pakanua, Kan Ho-Muong Mon faults), consistent with the locations where the aftershocks occurred.

If applying a larger scale to examine Dien Bien earthquake and its aftershocks along with other earthquakes in Dien Bien province (Fig. 3), Tuan Giao earthquake on 24 June 1983 (M =6.7), Lai Chau 1 earthquake on 1 January $2001(\mathrm{M}=4.5)$, Lai Chau 2 earthquake on 2 April $2001(\mathrm{M}=4.9)$, and the latest Dien Bien 2 earthquake on 9 January $2015(\mathrm{M}=4.7)$ (Table 2$)$, it can be observed that amongst the five earthquakes occurring from 1983 to present, three earthquakes occurred along LC-DB fault at different segments: Lai Chau 1, Lai Chau 2 and Dien Bien 1. Their epicentres were distributed in a strip extending in NE-SW direction, and their occurrence repeated in this direction. Lai Chau 1 earthquake occurred earliest on LC-DB fault at Lai Chau segment, followed by Dien Bien 1 earthquake on this fault at Dien Bien. Its epicentre shifted more towards SW direction compared to Lai Chau 1 earthquake. Subsequently, Lai Chau 2 earthquake also occurred on the right of this fault and its epicentre shifted more towards NE direction compared to two above-mentioned earthquakes. Thus, the seismicity in LC-DB area is quite active and the earthquake activities occur repeatedly along LC-DB fault. This process is the evidence that confirms the active and recent activities of LC-DB fault.

The results obtained is very important and seems to open a new approach in the study of earthquake activity characteristics, especially in active seismic regions based on the use of combinations of seismic, tectonic, geomorphic and remote sensing data.

$\mathrm{T}$ a b l e 2. Parameters of some earthquakes occurring in Dien Bien province.

\begin{tabular}{|c|l|c|c|c|c|c|c|c|c|}
\hline No. & Earthquake & Date & $\mathbf{h}$ & $\mathbf{m}$ & $\mathbf{s}$ & $\boldsymbol{\phi}^{\boldsymbol{o}} \mathbf{N}$ & $\boldsymbol{\lambda}^{\boldsymbol{}} \mathbf{E}$ & $\mathbf{H}(\mathbf{k m})$ & $\mathbf{M}$ \\
\hline 1 & Tuan Giao & 24.06 .1983 & 14 & 18 & 22.3 & 21.77 & 103.4 & 23 & 6.7 \\
\hline 2 & Lai Chau 1 & 01.01 .2001 & 11 & 34 & 21.1 & 21.84 & 103.146 & 1.1 & 4.5 \\
\hline 3 & Dien Bien 1 & 19.02 .2001 & 15 & 51 & 35.2 & 21.331 & 102.897 & 6.1 & 5.3 \\
\hline 4 & Lai Chau 2 & 02.04 .2001 & 20 & 45 & 48 & 22.103 & 103.236 & 0.1 & 4.9 \\
\hline 5 & Dien Bien 2 & 08.01 .2018 & 23 & 21 & 21.8 & 21.374 & 103.29 & 10 & 4.7 \\
\hline
\end{tabular}




\section{Conclusion}

The characteristics of Dien Bien earthquake on 19 February 2001 and its aftershocks have been studied and examined in detail. On the basis of the spatial distribution and temporal evolution of aftershock series of Dien Bien earthquake, its development in the source zone has been clarified, which consists of five aftershock series recurring on both sides of LC-DB fault and shifting towards different directions compared to the mainshock. This process is the evidence that not only indicates the consistency of seismic and tectonic data but also confirms the active and recent activities of LC-DB fault and other ones in this area. It is also the cause of Dien Bien earthquake and its aftershocks.

Examining the characteristics of aftershock activities of Dien Bien earthquake in relation to geomorphological features and tectonics activities in the area reveals that the magnitude of aftershock series and their temporal evolution (early or late) depend not only on the closer or further distance compared to the mainshock and the active faults that cause them but also on terrain elevation, slope index, lineament density and their positions relative to other tectonic faults in the studied area. Therefore, it is necessary to study in detail other earthquakes and their aftershocks in relation to geomorphological and tectonic features in order to clarify the mechanism and serve the prediction of aftershocks following the mainshock.

\section{Acknowledgements}

The authors would like to thank the support of the scientific research mission in 2018-2019 (Code: NVCC12.01/1818; NVCC12.01/19-19).

\section{References}

Barančoková, M. \& Kenderessy P. (2014). Assessment of landslide risk using GIS and statistical methods in Kysuce region. Ekológia (Bratislava), 33(1), 26-35. DOI: 10.2478/eko-2014-0004.

Belgherbi B., Benabdeli, K. \& Mostefai K. (2018). Mapping the risk forest fires in Algeria: Application of the forest of Guetarnia in Western Algeria. Ekológia (Bratislava), 37(3), 289-300. DOI: 10.2478/eko-2018-0022.

Bull, W.B. \& McFadden L.D. (1977).Tectonic geomorphology north and south of the Garlock fault, California. In D.O. Doehring (Ed.), Geomorphology in arid regions (pp. 115-138). Proceedings of the Eight Annual Geomorphology Symposium. Binghamton: State University New York.

Bull, W.B. (2007). Tectonic geomorphology of mountains: A new approach topaleoseismology. Oxford: Wiley-Blackwell. Cao Dinh Trieu (2001). The Thin Toc MS 5.3 earthquake in the 19 February 2001. Journal of Geology, Ser. A, 264(5-6), 1-14.

Le Tu Son (2004). Dien Bien Earthquake (Ms=5.3). Vietnam Journal of Earth Sciences, 26(2), 112-121.

Magulová, B. (2009). Using GIS for creation of geohazards map as a base for landuse planning (in Slovak). Acta Geologica Slovaca, 1(1), 25-32.

Ngo, Thi Lu (1999). Characteristics of seismicity and basic features of earthquake hypocenters in Southeast Asia from the viewpoint of elucidation of neotectonic structures (in Russian). Doctoral Thesis on Mathematics-Physics, Russian Academy of Sciences, Moscow.

Ngo, Thi Lu (2003). The correlation between earthquake magnitude values calculated by Vietnam's magnitude scale and by international data. Vietnam Journal of Earth Sciences, 25(3), 284-286.

Ngo, Thi Lu, Rodkin, M.V., Tran, Viet Phuong, Phung, Thi Thu Hang, Nguyen, Quang \& Vu Thi Hoan (2016). Algorithm and program for earthquake prediction based on the geological, geophysical, geomorphological and seismic data. Vietnam Journal of Earth Sciences, 38(3), 231-241.

Ngo, Thi Lu, Rodkin, V.M., Phuong, T.V., Quang, N., Hang, P.T.T. \& Hoan V.T. (2017). Assessment of earthquake hazard for the northwestern Vietnam from geological and geophysical data using an original program package. Journal of Volcanology and Seismology, 11(2), 164-171. DOI: 10.1134/S0742046317020063. 
Nguyen, Dinh Xuyen \& Nguyen Le Yem (1980). The assessment of magnitude scales of near earthquakes in Vietnam. In The results of research on geophysics in 1979 (pp. 79-100). Hanoi: Vietnam Academy of Science and Technology.

Nguyen, Hong Phuong, Nguyen Ta Nam \& Pham The Truyen (2018). Development of a Web-GIS based Decision Support System for earthquake warning service in Vietnam. Vietnam Journal of Earth Sciences, 40(3), 193-206.

Nguyen, Huu Tuyen \& Ngo Thi Lu (2012). Recognition of earthquake-prone nodes, a case study for North Vietnam $(\mathrm{M} \geq 5.0)$. Geodesy and Geodynamics, 3(2), 14-27. DOI: 10.3724/SP.J.1246.2012.00014.

Nguyen, Ngoc Thuy et al. (2005). The report on zoning for detailed earthquake prediction in the Northwest. The national project KC-08-10 in the period of 2001-2005. Hanoi: Institute of Geophysics.

Rodkin, M.V., Pisarenko, V.F., Ngo, Thi Lu \& Rukavishnikova T.A. (2014). On potential representations of the distribution law of rare strongest earthquakes. Geodynamics and Tectonophysics, 5(4), 893-904. DOI: 10.5800GT-2014-54-0161.

Seismological Bulletin of ISC (International Seismological Center) (2001).

Shebalin, N.V. (1971). Assessment of the size and location of the Tashkent earthquake focus on macroseismic and instrumental data (in Russian). In Tashkent earthquake 1966 (pp. 68-79). Tashkent: FAN.

Shebalin, N.V. (1974). Focus of strong earthquakes on the USSR territory (in Russian). Moscow: Science.

Zuchiewicz, W. \& Cuong N.Q. (2002). Morphotectonic and seismic properties of the Dien Bien Phu fault in Vietnam. In Program with Abstracts, IGCP 430 2nd Annual Workshop Mantle Responses to Tethyan Closure (pp. 84-85). April 1-10, 2002. Hanoi: Halong Bay City.

Zuchiewicz, W. \& Cuong N.Q. (2003). Strefa uskoku Dien Bien Phu w NW Wietnamie w świetle badań morfotektonicznych. In W. Zuchiewicz (Ed.), Materiały v Ogólnopolskiej Konferencji „Neotektonika Polski” Neotektonika a morfotektonika: metody badań (pp. 73-84). 26.-27.09.2003, Kraków. Kraków: Komisja Neotektoniki Komitetu Badań Czwartorzędu PAN, Instytut Nauk Geologicznych UJ, Galicia T. Group.

Zuchiewicz, W., Cuong, N.Q., Bluszcz, A. \& Michalik M. (2004). Quaternary sediments in the Dien Bien Phu fault zone, NW Vietnam: A record of young tectonic processes in the light of OSL-SAR dating results. Geomorphology, 60(3-4), 269-302. DOI: 10.1016/j.geomorph.2003.08.004. 